\title{
6. Strong economic rights, weak political rights in the EU: a constitutional cacophony
}

\section{Antonios Kouroutakis}

\section{INTRODUCTION}

From a legal and political perspective, the European Union (hereinafter EU) is a very ambitious project. On the one hand, it challenges the hierarchical structure of the ordinary constitutional systems of the Member States; on the other, it distorts the notion of national sovereignty and the unity of the political nature of the nation state.

The core achievement of the EU, and its heart, is the Single Market, which allows the free movement of goods, services, capital and workers within the EU. The Single Market was founded in 1986 with the Single European Act, ${ }^{1}$ which was the first major revision of the Treaty of $\mathrm{Rome}^{2}$ and was projected to be established by $1992 .{ }^{3}$

In particular, the free movement of workers, which was first established with the Treaty of Rome, ${ }^{4}$ is currently a fundamental right guaranteed by the Treaty on the Functioning of the European Union (hereinafter TFEU). ${ }^{5}$ Based on the provisions of the TFEU, EU citizens are entitled to move and reside freely within the territory of any of the Member States: ${ }^{6}$ to work there without needing a work permit; reside there for that purpose; and enjoy equal treatment

\section{Single European Act [1987] OJ L169/1.}

2 Treaty Establishing the European Community (Consolidated Version), Rome Treaty, 25 March 1957: see Article 13.

3 European Commission, Completing the Internal Market: White Paper from the Commission to the European Council COM(85) 310 final.

4 Treaty Establishing the European Community (Consolidated Version), Rome Treaty, 25 March 1957: see Article 48.

5 See Consolidated version of the Treaty on the Functioning of the European Union [2012] OJ C326/47, Article 45.

6 TFEU Article 20(2)(a). 
with nationals in access to employment without any discrimination based on nationality as regards employment, remuneration and other conditions. ${ }^{7}$

The right to move and reside freely within the territory of the Member States is one of the four components of EU citizenship. ${ }^{8}$ According to Eurostat, EU citizens living in an EU country other than their country of origin 'accounted in 2018 for $3.9 \%$ of total EU resident population, which was 1.2 pp more than in $2008^{\prime}$. ${ }^{9}$

Such free movement and the right to reside in another country in the EU have led to the following paradox: EU citizens who live in a country other than their country of origin have limited political rights to participate in their country of residence, and some of them have lost their political rights or have made it practically not possible to participate in the political life of their country of origin. This is what we call a "constitutional cacophony".

To exemplify this, I will use the case of the recent Brexit referendum in the UK. The aim is to highlight the paradox that EU citizens exercising their free movement rights, which are economic in nature, have in essence lost their political rights. What makes this case a prime paradigm is the fact that the referendum was based on the idea that UK membership of the EU had a core impact on the former's economic rights. This case, however, is far from unique; likewise, in Greece a referendum took place on a EU-related topic, and

\footnotetext{
7 TFEU Article 45(2).

8 See TFEU Article 20(2)(a). The other three components are, first, 'the right to vote and to stand as candidates in elections to the European Parliament and in municipal elections in their Member State of residence, under the same conditions as nationals of that State'; second, 'the right to enjoy, in the territory of a third country in which the Member State of which they are nationals is not represented, the protection of the diplomatic and consular authorities of any Member State on the same conditions as the nationals of that State'; and third 'the right to petition the European Parliament, to apply to the European Ombudsman, and to address the institutions and advisory bodies of the Union in any of the Treaty languages and to obtain a reply in the same language': see TFEU Article 20(2)(b), (c) and (d) respectively. For more details see Jo Shaw, 'Citizenship: Contrasting Dynamics at the Interface of Integration and Constitutionalism' in Paul Craig and Grainne De Burca, The Evolution of EU Law (OUP 2011) 575.

9 See Eurostat, EU citizens living in another Member State - statistical overview available at https://ec.europa.eu/eurostat/statistics-explained/index.php?title= EU_citizens_living_in_another_Member_State_-_statistical_overview\#Key_messages (accessed $2 \overline{1}$ November 2019). In particular, among EU citizens, the most numerous national groups of EU citizens aged 20-64 living in an EU country other than the country of their origin were from Romania (2,524,000 persons), Poland $(1,666,000$ persons), Italy (1,133,000 persons), Portugal (824,000 persons) and Bulgaria (562,000 persons).
} 
likewise, Greeks residing in another EU country could not vote. Nor could EU citizens residing in Greece. ${ }^{10}$

In the case of the UK, Brexit would have a severe impact on EU citizens who live and work in the UK. Likewise, Brexit would equally impact British people who live and work in the EU. What is common between these two groups, beside the fact that both groups have exercised their free movement rights, is that most of them did not have the right to participate in the referendum.

Such asynchronous condition between socioeconomic rights and political rights is facilitated by the constitutional framework of the EU. The Member States as masters of the Treaties have created a constitutional framework that respects their national sovereignty, for instance by limiting the political rights of third country EU nationals to vote in crucial elections such as national elections. This arrangement, however, is not in accordance with the ideals of democracy, as it creates a second class of citizens with limited political rights. Moreover, such arrangement signals a distrust in the EU nationals of third countries who reside in their territories, which is equally incompatible with the ideals of solidarity ${ }^{11}$ among the EU nations and Member States.

This chapter is structured as follows. Section 2 examines the scope and depth of EU citizens' political rights and will compare and contrast these in relation to their economic rights of free movement. Section 3 focuses on the recent referendum in the UK and examines the relevant legal framework. Having analysed the relevant legal framework and compared the legal framework of the Brexit referendum with that of the Scottish independence referendum, this chapter will conclude with a modest proposal to face such paradox. In particular, it will argue that Member States shall take measures at least to guarantee that on EU-related referenda, the electoral body shall be composed of both EU citizens residing within the country and nationals who reside in another EU country.

10 On paper, the referendum was about whether Greece should accept the bailout conditions proposed jointly by the European Commission (EC), the International Monetary Fund (IMF) and the European Central Bank (ECB), but in essence the participation of Greece in the eurozone was at stake. See Transcript of President Jean-Claude Juncker's press conference on Greece, 29 June 2015, https://ec.europa.eu/commission/ presscorner/detail/en/SPEECH_15_5274, accessed 21 June 2021.

11 On the principle of solidarity see Veronica Federico and Christian Lahusen (eds), Solidarity as a Public Virtue? (Nomos 2018) and for further discussion on the concept of solidarity see Garben, ch 9 in this volume. 


\section{STRONG ECONOMIC RIGHTS, WEAK POLITICAL RIGHTS}

The legal framework of the free movement of workers has been enhanced and even further developed and expanded in a series of cases. For instance, in an early case, the European Court of Justice clarified that Member States cannot "modify the meaning of the concept of "migrant worker" and [...] eliminate at will the protection afforded by the Treaty to certain categories of person'. ${ }^{12}$ Furthermore, the Court decided that EU workers' protection from discrimination has extraterritorial force, and therefore it is not relevant if the work was done outside the EU. In particular, if workers perform their duties in non-member states, they are protected from the principle of non-discrimination so long as the legal relationship of employment was entered within the Community. ${ }^{13}$

In addition, the orthodoxy is that the term 'worker' includes interns, part-time workers and jobseekers people, ${ }^{14}$ and the protection is expanded to their family members. ${ }^{15}$ Interestingly, while the scope of the right is interpreted widely, the limits and derogations are interpreted narrowly. ${ }^{16}$ For instance, on the power of the Member States to limit the free movement of workers on grounds of public policy, security, and health, ${ }^{17}$ the Court for instance states that Member States cannot interpret 'public policy' unilaterally without being subject to control by the EU. ${ }^{18}$ Likewise, the exception of Article 45 paragraph 4 pertaining to the exception of employment in the public service is also interpreted narrowly. ${ }^{19}$

12 Case 75/63 Mrs M. K. H. Hoekstra (née Unger) v Bestuur der Bedrijfsvereniging voor Detailhandel en Ambachten (Administration of the Industrial Board for Retail Trades and Businesses), ECLI:EU:C:1964:19.

13 Case C-214/94 Ingrid Boukhalfa v Bundesrepublik Deutschland, ECLI:EU:C: 1996:174.

14 Case C-292/89 The Queen v Immigration Appeal Tribunal, ex parte Gustaff Desiderius Antonissen, ECLI:EU:C:1991:80.

15 Directive 2004/38/EC of the European Parliament and of the Council of 29 April 2004 on the right of citizens of the Union and their family members to move and reside freely within the territory of the Member States [2004] OJ L158/77.

16 Case 139/85 R. H. Kempf v Staatssecretaris van Justitie, ECLI:EU:C:1986:223.

17 TFEU Article 45(3).

18 Case 36/75 Roland Rutili v Ministre de l'intérieur, ECLI:EU:C:1975:137.

19 Case 152/73 Giovanni Maria Sotgiu v Deutsche Bundespost, ECLI:EU:C:1974: 13. 
From analysis of the relevant case law, it is obvious that the Court has been very active in protecting the free movement of workers. ${ }^{20}$ Given the very comprehensive legal framework, Member States cannot limit the exercise of this right in practice. With regard to political rights, the Treaty of Lisbon includes a plethora of provisions which establish political rights for EU citizens. The political dimension of EU citizenship has come to compliment the economic dimension. As O’Leary has put it,

the establishment and gradual constitutionalization of Union citizenship further confirms this recognition of free movement rights as individual rights worthy of protection not simply when exercised in the pursuit of economic integration but in their own right, as benefits conferred on Member State nationals in the context of the creation of an ever closer union. ${ }^{21}$

Progressively in the text of the EU Treaties, general principles with political connotations appeared - such as democracy and solidarity - which were further specified with a number of provisions. ${ }^{22}$

To begin with, Article 20(2)(b) of the TFEU provides that EU citizens have "the right to vote and to stand as candidates in elections to the European Parliament and in municipal elections in their Member State of residence, under the same conditions as nationals of that State'. ${ }^{23}$ This right of political suffrage - to stand for elections, or passive suffrage, and to vote, or active suffrage - is further specified with more specific provisions in the TFEU and the EU Charter of Fundamental Rights. ${ }^{24}$ In particular, an EU citizen who resides 'in a Member State of which he is not a national shall have the right to vote and

20 Elsewhere, I have argued that judges at the CJEU are more keen to show activism when there is consensus in the political system. See Antonios Kouroutakis, 'Judges and Policy Making Authority in the United States and the European Union' (2014) 8(2) ICL Journal 186.

${ }^{21}$ Siofra O'Leary, 'Free Movement of Persons and Services' in Paul Craig and Grainne De Burca (ed), The Evolution of EU Law (OUP 2011) 507.

22 For more details regarding the initial values defended by the EU treaties see Federico Mancini, Democracy and Constitutionalism in the European Union: Collected Essays (Hart Publishing 2000) 31.

23 TFEU 20(2)(b). Moreover, the right to participation in political processes is complemented by the European Citizens' Initiative, which complies with the concept of participatory democracy, allowing one million EU citizens who reside in at least one quarter of the Member States to 'invite the Commission to submit a proposal for a legal act to implement the EU Treaties': see TFEU 24 and Regulation (EU) No 211/2011 of the European Parliament and of the Council of 16 February 2011 on the citizens' initiative [2011] OJ L65/1.

24 See Articles 39 and 40 CFREU. 
to stand as a candidate at municipal elections in the Member State in which he resides, under the same conditions as nationals of that State'. ${ }^{25}$

According to Article 22(2), and without prejudice to Article 223(1) and to the provisions adopted for its implementation, 'every citizen of the Union residing in a Member State of which he is not a national shall have the right to vote and to stand as a candidate in elections to the European Parliament in the Member State in which he resides, under the same conditions as nationals of that State'.

Both rights are subject to detailed arrangements with secondary legislation which may provide for derogations. ${ }^{26}$ Accordingly, in line with secondary legislation pertaining to municipal elections, national governments may decide that leaders of local and municipal authorities such as mayors can only be nationals of that country - thus excluding other EU citizens - and they may require a minimum period of residence for EU citizens in order to participate in local elections where EU citizens comprise more than 20 per cent of the voting population. ${ }^{27}$

Likewise, pertaining to the EU parliamentary elections, according to secondary legislation, a national government may require a minimum period of residence for EU citizens in order to participate in European elections, where EU citizens comprise more than 20 per cent of the voting population. ${ }^{28}$

Furthermore, the TFEU includes a specific provision requiring the Commission to report to the European Parliament, to the Council and to the Economic and Social Committee every three years. ${ }^{29}$ Accordingly, in 2017 the Commission reported Union developments on these issues and noted:

Being a European citizen also means enjoying political rights. Every adult EU citizen has the right to vote in European Parliament elections. Mobile EU citizens have the right to vote in their country of residence, or in their country of origin. This right is not exercised as fully as it could be. ${ }^{30}$

25 TFEU 22(1).

26 See TFEU 22(1) and 22(2) respectively.

27 See Council Directive 94/80/EC of 19 December 1994 laying down detailed arrangements for the exercise of the right to vote and to stand as a candidate in municipal elections by citizens of the Union residing in a Member State of which they are not nationals [1994] OJ L368/38.

28 See Council Directive 93/109/EC of 6 December 1993 laying down detailed arrangements for the exercise of the right to vote and stand as a candidate in elections to the European Parliament for citizens of the Union residing in a Member State of which they are not nationals [1993] OJ L329/34.

29 TFEU 25.

30 European Commission, Report on the EU Citizenship Report 2017: Strengthening Citizens' Rights in a Union of Democratic Change (2017/2069(INI)) p.17. 
Considering the relevant law, we conclude that EU citizens lacking the nationality of the Member State in which they reside have rather limited rights to vote and stand in national and regional elections in that state. ${ }^{31}$ Moreover, the Treaties do not regulate the rights of EU citizens who reside in another country to participate in voting in their country of origin during national, regional or local elections. ${ }^{32}$

In addition, it seems that EU citizens who reside in an EU Member State other than that of their nationality do not have a clear preference on where they want to vote. In particular, according to Eurobarometer 2015, regarding the EU parliamentary elections, ' $44 \%$ of Europeans say they would prefer to vote for the candidates in the country in which they are residing and $45 \%$ would prefer to vote for candidates in their country of origin'. ${ }^{33}$

The analysis above has shown that EU political rights are subject to an incomplete framework. Such incomplete legal framework was remarked upon by the Commission as long ago as 2004, when it stated: 'This loss of the right to vote in national elections in the country of nationality because of the exercise of the right to move in another EU country is perceived by Union citizens as a gap in their political rights. ${ }^{34}$

Given this, the Commission recommended that Member States of the EU that do not allow their citizens to vote because they are resident in another Member State should remove this residence condition and readmit their nationals to the electoral rolls. ${ }^{35}$ In practice, however, no steps were taken,

31 For more details see Jo Shaw, 'EU Citizenship and Political Rights in an Evolving European Union' (2007) 75 Fordham Law Review 2549.

32 Dimitry Kochenov, 'Free Movement and Participation in the Parliamentary Elections in the Member State of Nationality: An Ignored Link?' (2009) 16(2) Maastricht Journal of European and Comparative Law 197.

33 Flash Eurobarometer 431, Report Electoral Rights November 2015 p. 22.

34 European Commission, 2014/53/EU: Commission Recommendation of 29 January 2014 addressing the consequences of disenfranchisement of Union citizens exercising their rights to free movement [2014] OJ L32/34 [9].

35 ' 1 . Where Member States' policies limit the rights of nationals to vote in national elections based exclusively on a residence condition, Member States should enable their nationals who make use of their right to free movement and residence in the Union to demonstrate a continuing interest in the political life in the Member State of which they are nationals, including through an application to remain registered on the electoral roll, and by doing so, to retain their right to vote. 2. Where Member States allow their nationals residing in another Member State to retain their right to vote in national elections through an application to remain registered on the electoral roll, this should be without prejudice to the possibility for those Member States to put in place proportionate accompanying arrangements, such as reapplication at appropriate intervals. 3 . Member States that allow their nationals residing in another Member State to retain their right to vote in national elections through an application or a reapplication to 
as in 'five Member States the legal regimes currently applicable may lead to a situation where Union citizens residing in other Member States could lose their right to vote solely on the ground that they have been residing abroad for a certain period of time'; ${ }^{36}$ further, another country does not facilitate expats' right to vote.

Based on the primary and secondary law of the EU, a failure to synchronise socioeconomic and political rights is recorded. Such failure is not random but systemic. It is in reality a constitutional cacophony tolerated by the masters of the Treaty, which indicates the substantive priorities of the Union.

However, the socioeconomic dimension, when not coupled with the political dimension, leaves the Union vulnerable to crisis that exacerbates the lack of political context in the EU and makes the constitutional cacophony even louder. A crisis exemplifying such systemic failure at the EU was recorded during the Brexit process.

\section{THE EU CITIZENSHIP PARADOX AND THE CASE OF THE BREXIT REFERENDUM}

The EU citizenship paradox was exemplified in the recent Brexit referendum in the UK, which was EU-relevant. The question put to the electorate was whether UK should remain a member of or leave the EU. A fortiori, such decision would impact the rights of and the status quo for EU citizens who live in the UK, and the rights of UK citizens living in the EU.

The European Union Referendum Act, the law that set out the details of the referendum, was enacted in 2015. ${ }^{37}$ According to its section 2, those entitled to vote in the referendum were British, Irish and Commonwealth citizens living in the UK. ${ }^{38}$ This meant that even EU citizens from Malta and Cyprus could

remain registered on the electoral roll should ensure that all relevant applications may be submitted electronically. 4. Member States providing for the loss of the right to vote in national elections by their nationals residing in another Member State should inform them by appropriate means and in a timely manner about the conditions and the practical arrangements for retaining their right to vote in national elections.'

36 European Commission, 'Communication from the Commission to the European Parliament, the Council, the European Economic and Social Committee and the Committee of the Regions Addressing the consequences of disenfranchisement of Union citizens exercising their right to free movement COM/2014/033' final.

37 The European Union Referendum Act 2015 (c. 36).

38 The European Union Referendum Act 2015 (c. 36) section 2. 'Entitlement to vote in the referendum

(1) Those entitled to vote in the referendum are-

(a) the persons who, on the date of the referendum, would be entitled to vote as electors at a parliamentary election in any constituency, 
participate in such core political process. Britons who had lived abroad for fewer than 15 years could also vote. ${ }^{39}$

To begin with, the composition of the electoral body is a core issue related to the principle of national sovereignty and relevant to the principle of self-determination of each nation. This explains why the EU Member States are reluctant to extend to EU citizens the right to participate in states' core political processes. In reality, national sovereignty prevails and does not leave any room for mutual recognition of non-national EU citizens to participate in the political process. As a result, sovereignty outweighs both the principle of solidarity among Member States and the principle of democracy, by limiting participation and by creating a secondary class of EU citizens with limited political rights.

Interestingly, there exist counter-forces to reverse the equilibrium in favour of solidarity and democracy. During the referendum of 23 June 2016 an amendment was proposed, with the aim to allow the participation of EU nationals living in the UK. ${ }^{40}$ However, the amendment was rejected. ${ }^{41}$ This signals that the forces to reverse the primacy of sovereignty over solidarity and democracy at pan-European level are not currently in the ascendancy.

The 15-year rule meant some Britons who exercised their right of free movement in the EU were not given the right to vote. An amendment was proposed with the aim of allowing the participation of UK nationals having lived outside of the UK for more than 15 years, but it was rejected. ${ }^{42}$

The 15-year rule was challenged before numerous courts and on different legal grounds. It was found to be compatible with the European Convention on

(b) the persons who, on that date, are disqualified by reason of being peers from voting as electors at parliamentary elections but- (i)would be entitled to vote as electors at a local government election in any electoral area in Great Britain, (ii)would be entitled to vote as electors at a local election in any district electoral area in Northern Ireland, or (iii)would be entitled to vote as electors at a European Parliamentary election in any electoral region by virtue of section 3 of the Representation of the People Act 1985 (peers resident outside the United Kingdom), and

(c) the persons who, on the date of the referendum - (i)would be entitled to vote in Gibraltar as electors at a European Parliamentary election in the combined electoral region in which Gibraltar is comprised, and (ii) fall within subsection (2).

(2) A person falls within this subsection if the person is either-

(a) a Commonwealth citizen, or (b) a citizen of the Republic of Ireland.'

9 See section 3 of the Representation of the People Act 1985.

40 HC Deb (7 Sep 2015) Vol 599 Col 128.

${ }^{41}$ HC Deb (7 Sep 2015) Vol 599 Col 128.

42 HC Deb (7 Sep 2015) Vol 599 Col 129. 
Human Rights. ${ }^{43}$ Moreover, it was found to be compatible with EU law. In particular, a challenge was brought before the courts of the UK as to whether the 15-year rule, with regard to the EU referendum, was an unjustified restriction on the rights of free movement. ${ }^{44}$ The UK court rejected the claim and held that 'Parliament could legitimately take the view that electors who satisfy the test of closeness of connection set by the 15 year rule form an appropriate group to vote on the question whether the United Kingdom should remain a member of the European Union or leave the European Union'. ${ }^{45}$

While the UK courts did not send a preliminary question to the Court of Justice of the European Union (hereinafter the CJEU), the CJEU did examine a challenge to the 15-year rule on different grounds. After the UK notified the EU of its intention to withdraw from the EU in March 2017 according to Article 50 of the TFEU, and the Council decided to authorise the European Commission to open negotiations with the UK, UK nationals who were denied the right to vote in the referendum of 23 June 2016 because of the 15-year rule brought an annulment action in the General Court of the European Union under Article 263 of the TFEU. ${ }^{46}$

They asked the Court to quash decisions of the Council which they claimed breached EU law. In particular, the applicants claimed that

the Council and the United Kingdom should have sought judicial review of the constitutionality of the notification of the intention to withdraw pursuant to the principle of sincere cooperation provided for in Article 4(3) TEU, and that the Council should have requested the opinion of the Court as to the compatibility with the Treaties of depriving expatriate UK citizens of the right to vote and of their indirect representation by MPs, pursuant to Article 218(11) TFEU. They add that to dismiss the present action for inadmissibility would infringe the principle of democracy. ${ }^{47}$

43 The European Court of Human Rights first referred to this issue in Matthews $v$ United Kingdom (1999) 28 EHRR 361 (ECHR) [65]: 'persons who are unable to take part in elections because they live outside the jurisdiction, as such individuals have weakened the link between themselves and the jurisdiction.' However, in Shindler v The United Kingdom the ECtHR found that the 15-year rule is not a violation of Article 3 of Protocol No. 1 in restricting the right to Mr Shindler's right to free elections. See Shindler v The United Kingdom ECHR 19840/09; Bailii [2010] ECHR 2222.

${ }_{44}$ Shindler \& Anor v Chancellor of the Duchy of Lancaster [2016] EWHC 957 (Admin).

45 Shindler \& Anor $v$ Chancellor of the Duchy of Lancaster [2016] EWHC 957 (Admin) [58].

46 Case T-458/17, Harry Shindler and Others $v$ Council of the European Union, ECLI:EU:T:2018:838.

47 Case T-458/17 Shindler (n 46), [28]. 
However, the Court decided that the case was inadmissible because the Council decision was a preparatory decision which did not produce binding legal effects capable of affecting the applicants' interests. The CJEU likewise rejected the appeal. ${ }^{48}$

In the Shindler case the argument was raised that depriving EU citizens of their political rights due to their exercise of economic rights is an infringement of the principle of democracy, which is set out, inter alia, in the preamble to the EU Treaty, in Article 2 TEU and in the preamble to the Charter of Fundamental Rights of the European Union. The CJEU rejected such argument.

While the Court's stance was reasonable, as this was an issue relevant to the constitutional setting of the Member State, it confirms the EU constitutional cacophony. Although on paper the EU is founded on the ideals of democracy, in practice economic rights have more significance and political rights are of limited importance. Moreover, although the Court as an institution has shown activism on the establishment of the autonomy of the EU and on the expansion of economic rights, with its teleological methodology to interpret gaps in the text of the Treaties, with the exception of only a few cases ${ }^{49}$ the Court has shown deference to Member States regarding the political dimension of EU citizenship. ${ }^{50}$

While the judiciary is not well positioned to expand the constitutional fabric of the EU, it could have stressed such cacophony and urged Member States to take action in order to resolve it. Such action is not unprecedented for the judicial branch. For instance, in South Africa, the government outsourced management of the payment of pensions and social grants to a private entity through an unfair procedure; the Constitutional Court, although recognising the irregularities and declaring the contract invalid, did not suspend the operation of the contract because of its concern for the well-being of a large portion of citizens who are dependent to those benefits. ${ }^{51}$ Hence, the Court both

48 C-755/18 P Appeal brought on 30/11/2018 by Harry Shindler and Others against the judgment of the General Court (Ninth Chamber, Extended Composition) delivered on 26 November 2018 in Case T-458/17 Shindler and Others v Council, ECLI:EU:C: 2019:221.

49 See for instance Case C-300/04 M. G. Eman and O. B. Sevinger v College van burgemeester en wethouders van Den Haag, ECLI:EU:C:2006:545.

50 Weiler has argued that EU law was developed via legal means when the political process was unable to further develop EU law. See Joseph Weiler, 'The Community System: The Dual Character of Supranationalism' (1981) 1(1) Yearbook of European Law 267; Joseph Weiler, 'The Transformation of Europe' (1991) 100(8) Yale Law Journal 2403, 2412-31.

${ }_{51}$ Allpay Consolidated Investment Holdings (Pty) Ltd \& others $v$ Chief Executive Officer of the South African Social Security Agency \& others 2014 (4) SA 179 (CC) [78]. 
recognised the cacophony and at the same time ordered the political branch to remedy the situation.

In like manner, the CJEU could have recognised the disparity between socioeconomic and political rights, and could have urged the EU's and Member States' institutions with decision-making power to fulfil their duty to enhance EU citizens' political rights in accordance with the Treaties and the principle of democracy. In practice, such judicial stance is not unknown in the EU edifice. Suffice it to mention here the so-called Solange $I^{52}$ and Solange II cases. ${ }^{53}$ While the EU constitutional system lacked a human rights framework, the Constitutional Court of Germany recognised such cacophony ${ }^{54}$ and, years later, in accordance with the jurisprudence of the CJEU (at that time ECJ) on human rights, it showed more restraint. ${ }^{55}$

However, it is interesting to compare and contrast the recent referendum in Scotland on a similar topic: whether Scotland would remain part of the United Kingdom or become independent. This referendum indirectly had EU-related complications, as Scotland's departure from the Union would automatically have meant Scotland's departure from the EU. ${ }^{56}$ Interestingly, in the Scottish referendum all Britons, including English citizens, residing in Scotland had the right to vote, along with Irish and Commonwealth citizens living in Scotland, and, interestingly, citizens of the EU living there. ${ }^{57}$

52 Internationale Handelsgesellschaft mbH $v$ Einfuhr- und Vorratsstelle für Getreide und Futtermittel [1974] 2 CMLR 540.

53 Re Wünsche Handelsgesellschaft [1987] 3 CMLR 225.

54 Internationale Handelsgesellschaft $m b H \quad v$ Einfuhr- und Vorratsstelle für Getreide und Futtermittel [1974] 2 CMLR 540, 549-50. The Court ruled that in 'the hypothetical case of a conflict between Community law and [...] the guarantees of fundamental rights in the Constitution [...] the guarantee of fundamental rights in the Constitution prevails as long as the competent organs of the Community have not removed the conflict of norms in accordance with the Treaty mechanism'.

55 Re Wünsche Handelsgesellschaft [1987] 3 CMLR 225, 265.

56 Letter from José Manuel Barroso to Lord Tugendhat, dated 10 December 2012: www.parliament.uk/documents/lords-committees/economic-affairs/ScottishInd ependence/EA68_Scotland_and_the_EU_Barroso\%27s_reply_to_Lord_Tugendhat _101212.pdf (accessed 11 November 2019).

57 See Scottish Independence Referendum (Franchise) Act 2013, section 2: Those entitled to vote in an independence referendum

(1) A person is entitled to vote in an independence referendum if, on the date on which the poll at the referendum is held, the person is-

(a) aged 16 or over,

(b) registered in either- (i) the register of local government electors maintained under section 9(1)(b) of the 1983 Act for any area in Scotland, or (ii) the register of young voters maintained under section 4 of this Act for any such area,

(c) not subject to any legal incapacity to vote (age apart), and 
The Scottish referendum highlights a best practice in terms of the composition of the electoral body with regard to referenda that substantially affect EU citizenship. As a result, we would suggest that Member States should take measures to guarantee that where EU-related referenda are concerned, the electoral body shall include EU citizens residing within the country as well as nationals who reside in another EU country. The role of EU institutions in seeking to resolve this paradox and remedy such cacophony should not be underestimated. Given, for instance, that the Commission has already spotted the problem, it should take the initiative to create an environment of mutual trust among the Member States and work on relevant legislative proposals. Best practices should be commended and serve as exemplars for other Member States to replicate and develop further.

\section{CONCLUSION}

The analysis above has shown the theoretical and practical implications of the EU constitutional cacophony for EU citizenship. Despite the fact that the Treaties on a number of provisions refer to the idea of democracy, in practice the economic dimension of EU citizenship is more relevant. This has an impact on citizens' political rights, which are not equally protected, and under some circumstances the exercise of the economic rights de facto weakens the political rights.

This was shown with the Brexit referendum in particular, during which neither UK expats living in another EU country for more than 15 years, nor most of the EU citizens living in the UK, had the right to vote.

Such cacophony is caused mainly by Member States' reluctance to relinquish part of their sovereignty in order to implement the solidarity between peoples requested by the EU Treaties, by strengthening electoral participation and democracy at the national level.

While the composition of the electoral body is a core issue related to the principle of national sovereignty and relevant to the principle of self-determination of each nation, where a referendum is organised which substantially affects EU citizenship Member States should follow the paradigm of the Scottish referendum and include in the electoral body both EU citizens residing within the country and nationals who reside in another EU country.

(d) a Commonwealth citizen, a citizen of the Republic of Ireland or a relevant citizen of the European Union. 